\title{
Effect of the Bio-Insecticide; ( Xan-Tari , Bacillus thuringiensis) on Two of Stored Prodect Insects (Oryzaephilus surinamensis and Sitophilus granarius ) and Determination its Toxicity in Male albino rat
}

\author{
Naglaa F. Abdel-Hameid *, Reham SH. El-Daly *** Ahmed A. Darwish * K. A.H. Ali and Fawzy .F. Shalaby * \\ * Faculty of Agriculture, Benha University, Egypt. \\ ** Plant Protection Research Institute, Dokki, Giza, Egypt. \\ *** Department of Forensic Medicine \& Toxicology. Faculty of Vet. Med. Benha University.
}

\begin{abstract}
The was aimed to evaluate the efficacy of commercial product, Xan-Tari (Bacillus thuringiensis) at different concentrations against $O$. surinamensis and $S$. granaries adults showed that mortality increased by increasing the Xan-Tari concentration,period exposure and temperature for both insect species. Highest mortality took place at 25 and $30^{\circ} \mathrm{C}$. for $\mathrm{O}$. surinamensis. The highest mortality recorded against $S$. granaries occurred when treatments took place at $25^{\circ} \mathrm{C}$.

The results indicated that $S$. granarius was more succeptible to Xan-Tari treatment than O. surinamensis . The safety of Xan-Tari (Bacillus thuringiensis)on mammals was investigated by determining the toxicological effects on liver and kidney enzyme activities and its oxidative stress in male albino rats. In this study, 20 male albino rats (western strain) were divided into 2 groups, each of one 10 rats. First group kept was control, while the second was fed on diat of $400 \mathrm{~g}$ of wheat mixed well with Xan-Tari. It was administrated one time per day to the rats for 3 successive weeks quantity of food consumed rat averaged from $25-30 \mathrm{gm}$.

The obtained results showed significant increase in ALT, AST, creatinine, urea, uric acid, CAT, MDA and GSH in treated rats .
\end{abstract}

Key words: Oryzaephilus surinamensis, Sitophilus granaries, Bacillus thuringiensis, Oxidative stress, Nephrotoxicity, bio-insecticide, Xan-Tari.

\section{INTRODUCTION}

Stored product insect pests cause serious losses in weight and quality of the stored products during storage (Evans 1987). Among the stored-product beetles, Oryzaephilus surinamensis and Sitophilus granarius can be considered as major pest in storage of grain-based products (Campbell and Runnion 2003). These pests are major pests of stored grains and grain products in the tropics (Howe 1965, Agarwal $\boldsymbol{e t}$ al. 1979; Daglish et al. 1996).

Pesticides include hundreds of chemical substances distributed across broad chemical and functional classes, which are widely used in agriculture as plant protection products and in public health for prevention and control of vector-borne diseases. The worldwide use of these chemicals implies that humans are continuously exposed to single pesticides or to combination of various pesticides, often in low concentrations that may elicit similar effects despite belonging to different chemical families. (Rizzati et al.2016).

Natural insecticides contain chemical, mineral, and biological materials and some products are available commercially, e.g., pyrethrum, neem, spinosad, rotenone, abamectin, Bacillus thuringiensis (Bt), garlic, cinnamon, pepper, and essential oil products. The selectivity and safety of natural insecticides are not absolute and some natural compounds are toxic (Mohamed 2016)
O. surinamensis and $S$. granarius, are well-known store -grain pest (Bağci $\boldsymbol{e t}$ al. 2014). These insects have a nearly cosmopolitan distribution, occurring throughout all warm and tropical parts of the world (Hong et al. 2018).

These are store pests are found in various products and habitats, particularly in mills, fodder storages, and shops (Sinha and Watters 1985; Trematerra and Sciarretta 2004; Laszczak-Dawid et al. 2008).

The worldwide need to produce inexpensive and abundant food supply for a growing population it is a great challenge that is further complicated by concerns about risks to environmental stability and human health triggered by the use of pesticides (Huang $\boldsymbol{e t}$ al., 2002). The aim of this study was to evaluate the efficacy of Xan-Tari biopesticide depending Bacillus thuringiensis against adult of $O$. surinamensis and $S$. granarius at three different temperatures under laboratory conditions and evaluate the toxic effect of bio-pesticide on albion rats.

\section{Materials and Methods}

- Experimental insects:

Experiments took place on two species of stored product insect species, namely the saw-toothed grain beetle, Oryzaephilus surinamensis (L) (Silvanidae, Coleoptera) and the granary weevil, Sitophilus granarius (Coleoptera : Curculionidae ) were used in this study. Tests were performed in the stored product 
insect laboratory at the Plant Protection Department, Faculty of Agriculture, Benha University.

\section{- Rearing technique of stock culture:}

Insects of the two species were reared in glass jars (approx. $500 \mathrm{ml}$ ) containing about $200 \mathrm{~g}$ of sterilized and conditioned crushed wheat grains for $O$. surinamensis and whole wheat grains to $S$. granarius. The glass jars were covered with muslin. Insect cultures were kept under controlled conditions of $28 \pm 2{ }^{\circ} \mathrm{C}$ and $65 \pm 5 \% \mathrm{RH}$ at the rearing room of the laboratory. Wheat grains were treated by freezing at $18^{\circ} \mathrm{C}$ for 2 weeks before application to eliminate any possible infestation by any insect species. Around 1000 adults of each insect species (1-2 weeks old) were introduced into the jars for egg laying and then kept at $28 \pm 2{ }^{\circ} \mathrm{C}$ and $65 \pm 5 \% \mathrm{RH}$, three days later. All insects were separated from the food, and the jars were kept again at the controlled conditions in the rearing room. This procedure was repeated several times in order to obtain large numbers of the adults (1-2 weeks old) needed to carry out the experiments during this study. The foods in the jars were renewed when ever necessary.

\section{- The tested stage:}

Adults of $O$. surinamensis and S. granarius (1-2 weeks old) were taken for the experiment.

\section{- Preparation of the tested insects:}

Groups of 20 adults each from, $O$. surinamensis and $S$. granarius were used in all experiments of the bio-insecticide.

\section{- Tested temperature and humidity:}

All experiments were conducted under constant temperatures 20,25 or $30{ }^{\circ} \mathrm{C}$ and $65 \pm 5 \% \mathrm{RH}$.

- Xan-Tari , (Bacillus thuringiensis) on $O$.

surinamensis and $S$. granarius:-

Twenty adults of each insect species, (1-2 weeks old) were placed in wire guaze cages (14 mm diam. and $45 \mathrm{~mm}$ long, filled with about $10 \mathrm{gm}$ crushed wheat grains for $O$. surinamensis and $10 \mathrm{~g}$ wheat whole seeds for $S$. granarius and the cages were closed by rubber stoppers. The cages were then, introduced into the $0.55^{-\mathrm{L}}$ gasight Dreshel exposure flasks. Insects in the flasks were treated for different exposure periods at $20 \pm 1,25 \pm 1$ or/and $30 \pm 1^{\circ} \mathrm{C}$ and $65 \pm 5 \% \mathrm{RH}$. The tested insects were allowed to feed on food treated at five concentrations of Xan-Tari $(0.625,1.25,2.5,5.0$ and $10.0 \mathrm{~g} / 100 \mathrm{ml}$ distilled water). Each concentration was assayed on 4 insects with 5 replications, thus twenty insects were treated with each concentrations. Another 20, insects divided into 5 replicates, received distilled water treatments as control. After treatment, the insects were, daily, examined for 25 days and the dead insects were counted and consequently percentages were calculated.

Evaluation of the safety of the tested product:
The present study was carried out on a total number of 20 white Albino male rats weighing 150$200 \mathrm{~g} /$ rat. Rats were obtained from Center of Experimental Laboratory Animal, Faculty of Veterinary Medicine, Benha University, Egypt.All rats were acclimatized for one week prior to the experiment. All rats received standard laboratory balanced commercial diet and water.

\section{Tested substance:}

Xan-Tari $54 \%$ DF

xanTari is the world's only biological insecticide containing a natural, potent strain (ABTS-1857) of the microorganism Bacillus thuringiensis subspecies aizawai (Bta) State. This product obtained from Valet BioScience LLC. USA. The recommended dose of xanTari was $1 \mathrm{~g} / \mathrm{L}$ of water.

Xan-Tari 54 prepared by add $10 \mathrm{mg}$-Xan-Tari /100 $\mathrm{ml}$ douple D.W and mixed good by using magnetic stirrer to more dissolve. Then take $20 \mathrm{ml}$ from stock solution and added to $400 \mathrm{~g}$ of wheat which previous prepared then mixed well by large spoon . It was administrated one time per day in which each rat eat average from 25 to $30 \mathrm{~g}$.

\section{Experimental design:}

In the present study male albino rats were randomly assigned into 2 equal groups 10 rats each.

Group I: kept as control.

Group II: received Xan-Tari as rat consumed once daily on diet for 3 weeks .

\section{Sampling:-}

Serum samples: - Blood samples collected in 7, 14 and 21 day. Whole blood collected in clean dry centrifuge tubes, allowed to stand for one hour at room temperature till clotted and centrifuged at $3000 \mathrm{rpm}$ for 15 minutes for serum separation, and kept at $-20^{\circ} \mathrm{C}$ till biochemical analysis.

\section{Biochemical analysis:-}

Serum ALT and AST were performed according to Safety Data Sheet (2002). While serum urea was detected according to Murray et al. (1984), serum creatinine was detected according to Husdan and Rapaport (1968) and serum urea was detected according to Tietz (1995)

\section{Evaluation of serum oxidative stress markers}

Serum used for assessment of MDA to levels calorimetrically according to Ohkawa et al. (1979), CAT to levels calorimetrically according to Aebi (1984) and GSH to levels calorimetrically according. to Ellman (1959).

\section{Statistical analysis:}

A probit computer program of Noack and Reichmuth (1978) and Finney (1971). Cumulative mortality at the end of the experiment was analyzed by ANOVA. The concentrations causing 50 and $90 \%$ 
mortalities, (LC50 \& LC90) and time needed for causing 50 and $90 \%$ cumulative mortalities (LT50 \& LT90) were determined using the probit analysis program LPD-line (Bakr 2005).

\section{Results and Discussion}

1- Effect and toxicity of different concentrations of the commercial product, Bacillus thuringiensis (Xan - Tari) against the two species of stored product insects, $O$. surinamensis and $S$. granarius.

a- Against $O$. surinamensis:-

The effect of Bacillus thuringiensis (XanTari) on the adult mortality of $O$. surinamensis at 20, 25 and $30^{\circ} \mathrm{C}$ was presented in Table (1). The results showed that the mortality increased by increasing the Xan-Tari concentration and exposure period under the three temperature values. At $20^{\circ} \mathrm{C}$, the adult mortality of $O$. surinamensis after 5 days exposure period was
$3.33 \%$ at concentration $0.0625 \mathrm{~g} / 100 \mathrm{ml}$ concentration, this percentage increased after 21 days post treatment to reach $62.22 \%$ at $10.0 \mathrm{~g} / 100 \mathrm{ml}$ concentration. At $25^{\circ} \mathrm{C}$, the mortality was $2.22 \%$ after 5 days exposure period with $0.0625 \mathrm{~g} / 100 \mathrm{ml}$ concentration and increased after 21 days to $61.11 \%$ with $10.0 \mathrm{~g} / 100 \mathrm{ml}$ concentration. At $30^{\circ} \mathrm{C}$, the mortality was $3.33 \%$ after 5 days exposure period at $0.0625 \mathrm{~g} / 100 \mathrm{ml}$ concentration and increased after 21 days post treatment to $70.00 \%$ at $10.0 \mathrm{~g} / 100 \mathrm{ml}$ concentration. Only at $25{ }^{\circ} \mathrm{C}$ some control larvae died after 5, 7, 10 and 14 days exposure period. Highest mortality rates were recorded when treatments took place at 25 and $30{ }^{\circ} \mathrm{C}$. It is clear from Table, 8 that mortality $\%$ increased with increasing the applied concentration and prolongation at the period after treatment under 20,25 and $30^{\circ} \mathrm{C}$.

Table 1. Mean cumulative mortality percentages amang $O$. surinamensis adults treated at 20,25 and $30{ }^{\circ} \mathrm{C}$ with commercial product of Bacillus thuringiensis (Xan-Tari) at different concentrations.

\begin{tabular}{|c|c|c|c|c|c|c|}
\hline \multirow{2}{*}{$\begin{array}{c}\text { Concentrati-on } \\
(\mathrm{mg} / \mathbf{1 0 0})\end{array}$} & \multicolumn{5}{|c|}{ Exposure (day) } & \multirow{2}{*}{$\begin{array}{c}\text { Mean of } \\
\text { period }\end{array}$} \\
\hline & 5 & 7 & 10 & 14 & 21 & \\
\hline \multicolumn{7}{|c|}{ at $20^{\circ} \mathrm{C}$} \\
\hline$(\mathbf{1 . 2 5})$ & $5.56 \pm 1.11^{\mathrm{cE}}$ & $10.00 \pm 1.92^{\mathrm{dD}}$ & $14.44 \pm 2.94^{\mathrm{dC}}$ & $18.89 \pm 2.94^{\mathrm{dB}}$ & $25.56 \pm 2.94^{\mathrm{dA}}$ & $14.89 \pm 2.08^{d}$ \\
\hline (2.50) & $5.56 \pm 1.11^{\mathrm{cE}}$ & $12.22 \pm 1.11^{\mathrm{cD}}$ & $20.00 \pm 1.92^{\mathrm{cC}}$ & $24.44 \pm 2.94^{\mathrm{cB}}$ & $33.33 \pm 3.33^{\mathrm{cA}}$ & $19.11 \pm 2.71^{\mathrm{c}}$ \\
\hline (5.0) & $7.78 \pm 1.11^{\mathrm{bE}}$ & $15.56 \pm 1.11^{\mathrm{bD}}$ & $25.56 \pm 1.11^{\mathrm{bC}}$ & $35.56 \pm 1.11^{\mathrm{bB}}$ & $46.67 \pm 0.00^{\mathrm{bA}}$ & $26.22 \pm 3.72^{b}$ \\
\hline (10.0) & $11.11 \pm 1.11^{\mathrm{aE}}$ & $22.22 \pm 1.11^{\mathrm{aD}}$ & $34.44 \pm 1.11^{\mathrm{aC}}$ & $47.78 \pm 1.11^{a B}$ & $62.22 \pm 2.22^{\mathrm{aA}}$ & $35.56 \pm 4.87^{a}$ \\
\hline Mean & $5.56 \pm 0.89^{\mathrm{E}}$ & $10.93 \pm 1.76^{\mathrm{D}}$ & $17.04 \pm 2.8 \mathrm{C}$ & $22.59 \pm 3.92^{\text {B }}$ & $30.00 \pm 5.07^{\mathrm{A}}$ & \\
\hline \multirow{2}{*}{ LSD at 0.05 for } & \multicolumn{2}{|c|}{ Concentration $(\mathbf{C})$} & \multicolumn{2}{|c|}{ Period $(\mathbf{P})$} & \multicolumn{2}{|c|}{$\mathbf{C} * \mathbf{P}$} \\
\hline & \multicolumn{2}{|c|}{2.12} & \multicolumn{2}{|c|}{1.93} & \multicolumn{2}{|c|}{4.73} \\
\hline$(0.625)$ & $2.22 \pm 1.11^{\mathrm{eE}}$ & $5.56 \pm 1.11^{\mathrm{eD}}$ & $\begin{array}{l}\text { at } 25^{\circ} \mathrm{C} \\
8.89 \pm 1.11^{\mathrm{eC}}\end{array}$ & $11.11 \pm 1.11^{\mathrm{eB}}$ & $13.33 \pm 1.93^{\mathrm{eA}}$ & $8.22 \pm 1.17^{\mathrm{e}}$ \\
\hline$(\mathbf{1 . 2 5})$ & $5.56 \pm 1.11^{\mathrm{dE}}$ & $11.11 \pm 2.22^{\mathrm{dD}}$ & $16.67 \pm 1.93^{\mathrm{dC}}$ & $22.22 \pm 1.11^{\mathrm{dB}}$ & $28.89 \pm 1.11^{\mathrm{dA}}$ & $16.89 \pm 2.26^{\mathrm{d}}$ \\
\hline (2.50) & $7.78 \pm 1.11^{\mathrm{cE}}$ & $15.56 \pm 1.11^{\mathrm{cD}}$ & $24.44 \pm 1.11^{\mathrm{cC}}$ & $32.22 \pm 1.11^{\mathrm{cB}}$ & $40.00 \pm 1.92^{\mathrm{cA}}$ & $24.00 \pm 3.11^{\mathrm{c}}$ \\
\hline (5.0) & $10.00 \pm 0.00^{\mathrm{bE}}$ & $21.11 \pm 1.11^{b D}$ & $30.00 \pm 1.92^{\mathrm{bC}}$ & $40.00 \pm 1.92^{\mathrm{bB}}$ & $50.00 \pm 1.92^{\mathrm{bA}}$ & $30.22 \pm 3.79^{b}$ \\
\hline T5 (10.0) & $11.11 \pm 1.11^{\mathrm{aE}}$ & $23.33 \pm 1.93^{\mathrm{aD}}$ & $34.44 \pm 2.94^{\mathrm{aC}}$ & $46.67 \pm 3.85^{\mathrm{aB}}$ & $61.11 \pm 2.94^{\mathrm{aA}}$ & $35.33 \pm 4.78^{a}$ \\
\hline Mean & $6.30 \pm 0.97^{E}$ & $12.96 \pm 20^{\mathrm{D}}$ & $19.26 \pm 2.90^{\mathrm{C}}$ & $25.55 \pm 3.91^{\text {B }}$ & $32.59 \pm 4.98^{\mathrm{A}}$ & \\
\hline \multirow{2}{*}{ LSD at 0.05 for } & \multicolumn{2}{|c|}{ Concentration $(\mathrm{C})$} & \multicolumn{2}{|c|}{ Period $(\mathbf{P})$} & \multicolumn{2}{|c|}{$\mathbf{C} * \mathbf{P}$} \\
\hline & \multicolumn{2}{|c|}{0.73} & \multicolumn{2}{|c|}{0.67} & \multicolumn{2}{|c|}{1.63} \\
\hline$(0.625)$ & $3.33 \pm 0.00^{\mathrm{dE}}$ & $5.56 \pm 1.11^{\mathrm{eD}}$ & $\begin{array}{l}\text { at } 30^{\circ} \mathrm{C} \\
8.89 \pm 1.11^{\mathrm{eC}}\end{array}$ & $12.22 \pm 1.11^{\mathrm{eB}}$ & $14.44 \pm 1.11^{\mathrm{eA}}$ & $8.89 \pm 1.16{ }^{\mathrm{e}}$ \\
\hline$(1.25)$ & $4.44 \pm 1.11^{\mathrm{dE}}$ & $8.89 \pm 1.11^{\mathrm{dD}}$ & $13.33 \pm 1.93^{\mathrm{dC}}$ & $18.89 \pm 2.94^{\mathrm{dB}}$ & $23.33 \pm 3.85^{\text {dA }}$ & $13.78 \pm 2.03^{d}$ \\
\hline$(2.50)$ & $7.78 \pm 1.11^{\mathrm{cE}}$ & $15.55 \pm 2.22^{\mathrm{cD}}$ & $23.33 \pm 1.93^{\mathrm{cC}}$ & $31.11 \pm 4.01^{\mathrm{cB}}$ & $37.78 \pm 4.01^{\mathrm{cA}}$ & $23.11 \pm 3.06^{c}$ \\
\hline (5.0) & $11.11 \pm 1.11^{\mathrm{bE}}$ & $21.11 \pm 1.11^{b D}$ & $31.11 \pm 1.11^{\mathrm{bC}}$ & $40.00 \pm 0.00^{\mathrm{bB}}$ & $50.00 \pm 0.00^{\mathrm{bA}}$ & $30.67 \pm 3.67^{b}$ \\
\hline (10.0) & $13.33 \pm 0.00^{\mathrm{aE}}$ & $26.67 \pm 0.00^{\mathrm{aD}}$ & $38.89 \pm 1.11^{\mathrm{aC}}$ & $54.44 \pm 1.11^{\mathrm{aB}}$ & $70.00 \pm 1.92^{\mathrm{aA}}$ & $40.67 \pm 5.36^{a}$ \\
\hline Mean & $6.67 \pm 1.14^{E}$ & $12.96 \pm 2.25^{\mathrm{D}}$ & $19.26 \pm 3.25^{\mathrm{C}}$ & $26.11 \pm 4.43^{B}$ & $32.59 \pm 5.67^{\mathrm{A}}$ & \\
\hline & \multirow{2}{*}{\multicolumn{2}{|c|}{$\begin{array}{c}\text { Concentration }(\mathrm{C}) \\
2.15\end{array}$}} & \multirow{2}{*}{\multicolumn{2}{|c|}{$\begin{array}{c}\text { Period }(\mathbf{P}) \\
1.96\end{array}$}} & \multirow{2}{*}{\multicolumn{2}{|c|}{$\begin{array}{r}\mathbf{C} * \mathbf{P} \\
4.80\end{array}$}} \\
\hline LSD at 0.05 for & & & & & & \\
\hline
\end{tabular}

$\mathrm{a}, \mathrm{b} \& \mathrm{c}$ : There is no significant difference $(\mathrm{P}>0.05)$ between any two means, within the same column have the same superscript letter.

A, B \& C: There is no significant difference $(\mathrm{P}>0.05)$ between any two means, within the same row have the same superscript letter.

\section{b- Against $S$. granarius:-}

Results in Table (2) showed the cumulative mortality percentages of Sitophilus granarius after 5, $7,10,14$ and 21 days as well as at 20,25 and $30{ }^{\circ} \mathrm{C}$. Where at $20^{\circ} \mathrm{C}$, the adult mortality of $S$. granarius after 5 days exposure period was $3.33 \%$ at $0.0625 \mathrm{~g} /$ $100 \mathrm{ml}$ concentration, while the mortality increased after 21 days post treatment to reach $81.11 \%$ at 10.0 $\mathrm{g} / 100 \mathrm{ml}$ concentration.

At $25^{\circ} \mathrm{C}$, the mortality was $4.44 \%$ after 5 days exposure period with $0.0625 \mathrm{~g} / 100 \mathrm{ml}$ concentration and increased after 21 days to $86.67 \%$ with $10.0 \mathrm{~g} /$ $100 \mathrm{ml}$ concentration.

At $30^{\circ} \mathrm{C}$, the mortality was $4.44 \%$ after 5 days exposure period at $0.0625 \mathrm{~g} / 100 \mathrm{ml}$ concentration and increased after 21 days post treatment to $85.56 \%$ at $10.0 \mathrm{~g} / 100 \mathrm{ml}$ concentration. Most control larvae died at 20, 25 and $30{ }^{\circ} \mathrm{C}$ after 5, 7, 10 and 14days exposure period. Highest mortality rates were recorded when treatments took place at $25{ }^{\circ} \mathrm{C}$. It is clear from Table, (9) that mortality $\%$ increased with increasing the applied concentration and prolongation of the period after treatment under 20,25 and $30^{\circ} \mathrm{C}$ 
Table 2. Mean cumulative mortality percentages of $S$. granarius treated at 20,25 and $30{ }^{\circ} \mathrm{C}$ with commercial product of Bacillus thuringiensis (Xan-Tari) at different concentrations.

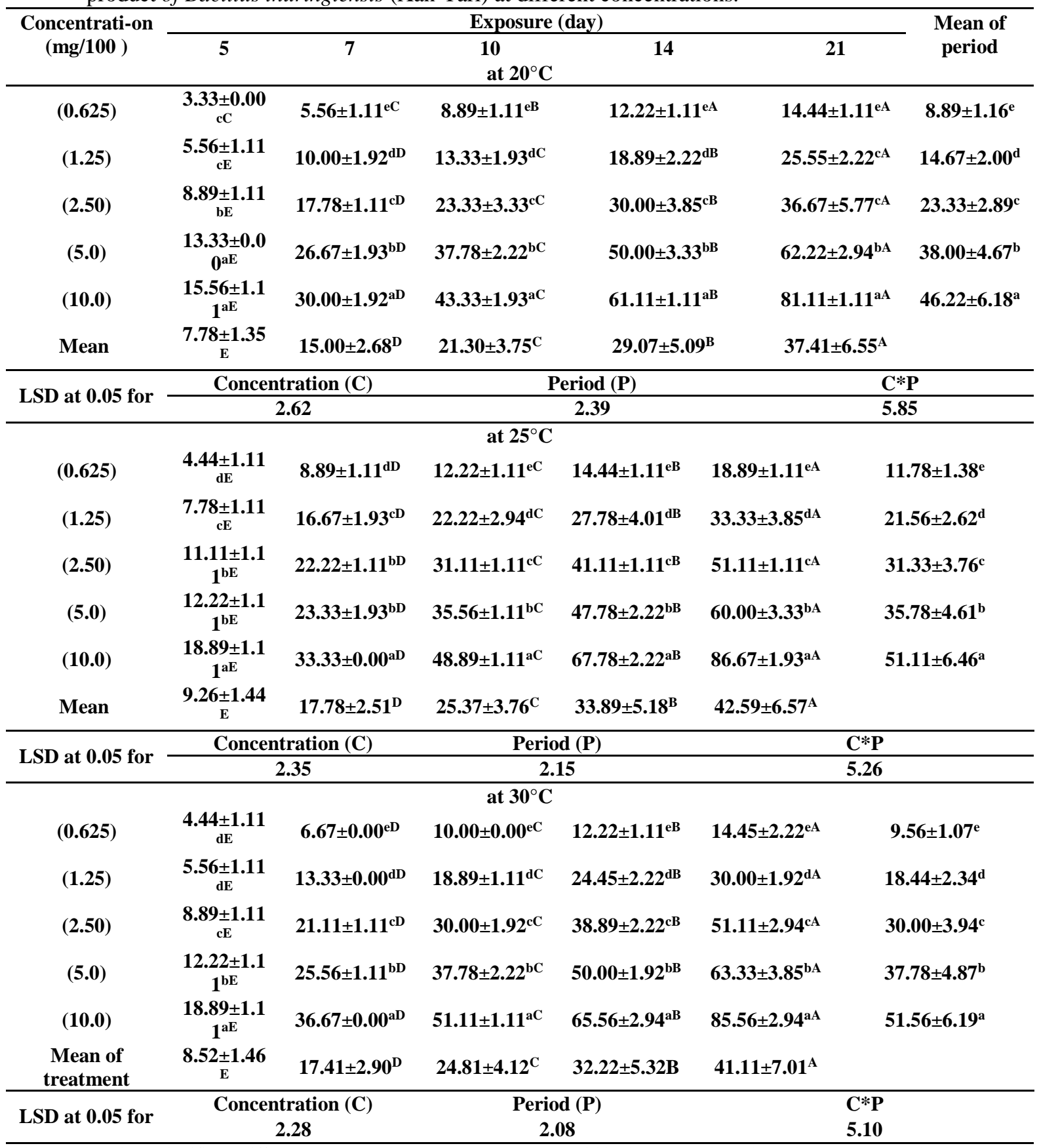

a, b \& c: There is no significant difference $(\mathrm{P}>0.05)$ between any two means, within the same column have the same superscript letter.

A, B \& C: There is no significant difference $(\mathrm{P}>0.05)$ between any two means, within the same row have the same superscript letter.

- Lethal toxicity of the commercial product, Bacillus thuringiensis (Xan-Tari) against, $O$. surinamensis and S. granarius at 20,25 and $30{ }^{\circ} \mathrm{C}$.

a. Against $O$. surinamensis:

The lethal concentrations of the tested commercial product ( Xan-Tari) on the adult stage of $O$. surinamensis are shown in Table (3). As a general, the concentration $10 \mathrm{~g} / 100 \mathrm{ml}$ (higher concentration) caused the highest mortality and vice versa. The three tested temperature $\left(20,25\right.$ and $\left.30^{\circ} \mathrm{C}\right)$ behaved different in their reaction. Tested commercial product ( Xan-Tari) gave different mortalities to adults of $O$. surinamensis at the different levels of concentrations and different temperatures. At $30^{\circ} \mathrm{C}$, adults of $O$. surinamensis show the high susceptible and low $\mathrm{LC}_{50}$ $(24.042 \mathrm{~g} / 100 \mathrm{ml})$. On contrary at $20^{\circ} \mathrm{C}$, adults of $O$. surinamensis manifested least susceptibility as those showed the highest $\mathrm{LC}_{50}(24.9424 \mathrm{~g} / 100 \mathrm{ml})$. In this respect, at $25^{\circ} \mathrm{C}$ showed intermediate position in their susceptibility to $B$. thuringiensis treatments between the 20 and $30{ }^{\circ} \mathrm{C}$ ( $\mathrm{LC}_{50}$ was $\left.22.857 \mathrm{~g} / 100 \mathrm{ml}\right)$.

b. Against $S$. granarius: 
The lethal concentrations of the tested commercial product ( Xan-Tari) on the adult stage of $S$. granarius are shown in Table (3). As a general, the concentration $10 \mathrm{~g} / 100 \mathrm{ml}$ highest concentration caused the highest mortality and vice versa. The tested temperatures $\left(20,25\right.$ and $\left.30^{\circ} \mathrm{C}\right)$ behaved different in their reaction to $B$. thuringiensis treatment. Adults of $S$. granarius gave different mortalities effect to tested commercial product ( Xan-Tari) at different levels of concentrations and different temperatures. At $30^{\circ} \mathrm{C}$, adults of $S$. granarius were the highest susceptible, showing the lowest $\mathrm{LC}_{50}(8.334 \mathrm{~g} / 100 \mathrm{ml})$.

Table 3. The lethal concentrations of the tested commercial product ( Xan-Tari ) against the adults of $O$. surinamensis and S. granarius at 20,25 and $30{ }^{\circ} \mathrm{C}$.

\begin{tabular}{|c|c|c|c|c|c|}
\hline Temperature ${ }^{\circ} \mathrm{C}$ & Insect & $\mathbf{L C}_{50}$ & Slope & P-value & R (Tab. 878) \\
\hline \multirow{2}{*}{20} & O. surinamensis & $\begin{array}{c}24.0424 \\
(14.2837-113.4244)\end{array}$ & $0.8941 \pm 0.1602$ & 0.9685 & 0.9956 \\
\hline & S. granarius & $\begin{array}{c}9.0950 \\
(6.4586-15.5007)\end{array}$ & $1.0444 \pm 0.1498$ & 0.7788 & 0.9906 \\
\hline \multirow{2}{*}{25} & O. surinamensis & $\begin{array}{c}24.9424 \\
(13.2336-89.4786)\end{array}$ & $0.8437 \pm 0.1574$ & 0.6906 & 0.9792 \\
\hline & S. granarius & $\begin{array}{c}10.2855 \\
(7.3950-17.0417)\end{array}$ & $1.1725 \pm 0.1579$ & 0.9530 & 0.9974 \\
\hline \multirow{2}{*}{30} & O. surinamensis & $\begin{array}{c}22.8570 \\
(12.0946-84.6158)\end{array}$ & $0.7938 \pm 0.1527$ & 0.9991 & 0.9995 \\
\hline & S. granarius & $\begin{array}{c}8.3341 \\
(5.9810-13.8751)\end{array}$ & $1.0339 \pm 0.1481$ & 0.9989 & 0.9998 \\
\hline
\end{tabular}

On contrary at 20 and $25^{\circ} \mathrm{C}$, adults of $S$. granarius manifested least susceptibility as those showed the highest $\mathrm{LC}_{50}$. The results indicated that $S$. granarius was more sensitive to the Xan-Tari. All the tested concentrations of commercial product (Xan-Tari) significantly killed $S$. granarius and adversely affected the post treatment population build-up of the insect.

\section{2- Effect of Xan-Tari on biochemical parameters of tested rats:}

ALT, AST, Urea, Creatinine and Uric acid results showed a significant increase in exposed groups (receive XENTARI) in comparison to control. Level of ALT showed in Fig. (1), Level of AST showed in Fig. (2), Level of Urea showed in Fig. (3), Level of uric acid showed in Fig. (4) and level of creatinine showed in Fig. (5) .There were highly significant increase in exposed groups and this increases gradually with prolong exposure if compare with the control group.

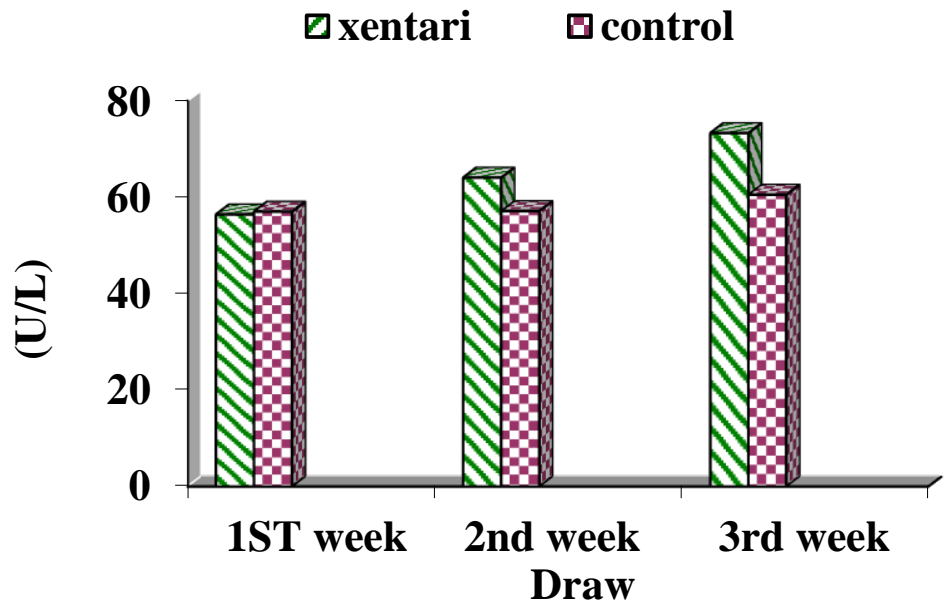

Fig. (1)) Showed ALT level (ULL) in rat's serum at $1^{\text {st }}$, 2nd and $3^{\text {rd }}$ weeks of the experiment. 


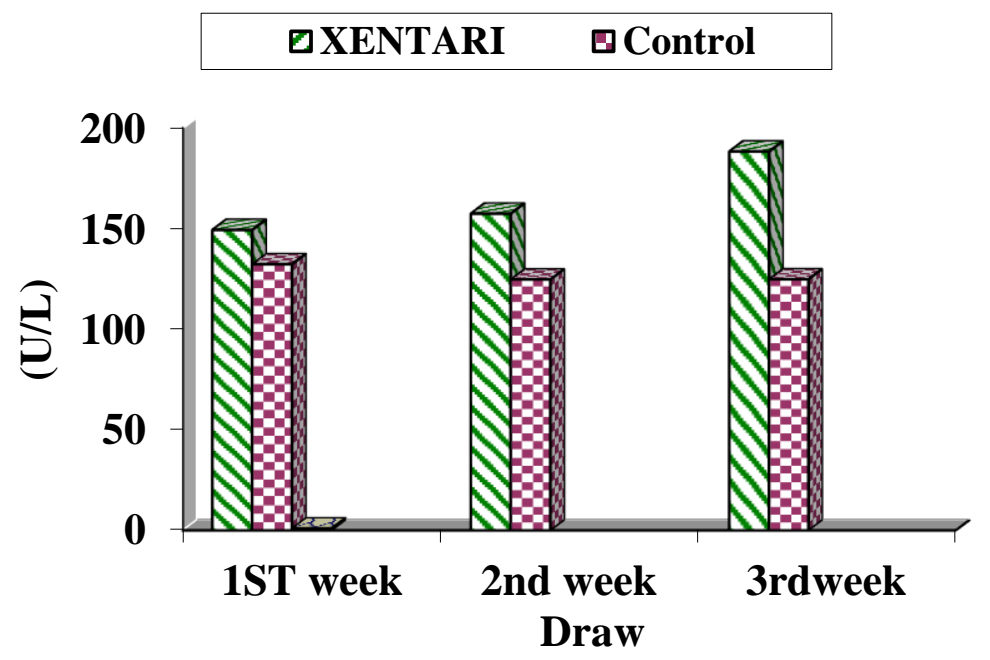

Fig. (2) Showed AST level (UlL) in rat's serum at $1^{\text {st }}$, 2nd and $3^{\text {rd }}$ weeks of the experiment.

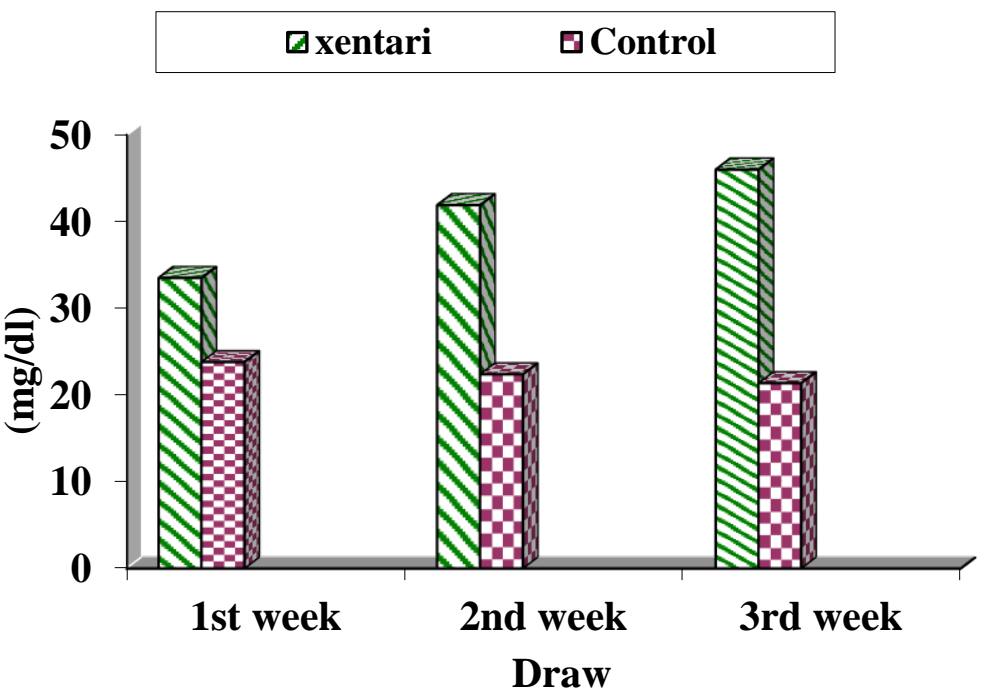

Fig. (3) Showed urea level $(\mathrm{mg} / \mathrm{dl})$ in rat's serum at $1^{\text {st }}$, 2 nd and $3^{\text {rd }}$ weeks of the experiment. 


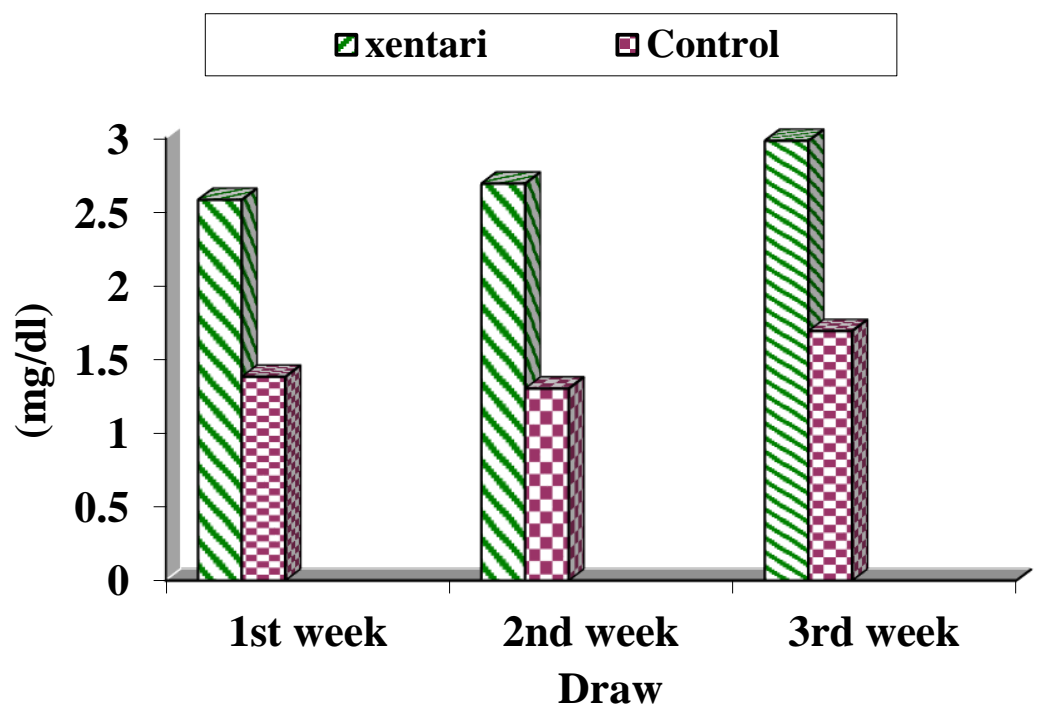

Fig. (4) Showed uric acid level $(\mathrm{mg} / \mathrm{dl})$ in rat's serum at $1^{\text {st }}, 2$ nd and $3^{\text {rd }}$ weeks of the experiment.

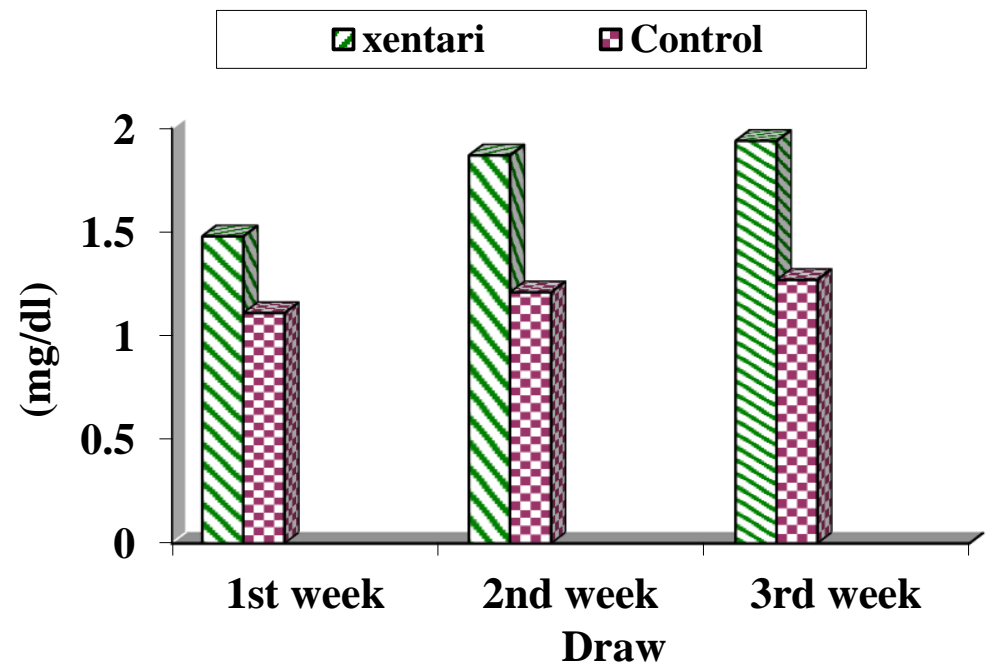

Fig. (5) Showed Creatinine level (mg/dl) in rat's serum at $1^{\text {st }}$, 2nd and $3^{\text {rd }}$ weeks of the experiment.

3- Effect of Xan-Tari on Antioxidant Level in serum of tesed rats:

Catalase (CAT), Malondialdehyde (MDA) and Reduce glutathione(GSH), showed a significant increase in exposed groups (receive XENTARI) in comparison to control. Level of CAT showed in Fig. (6), Level of MDA showed in Fig. (7), and level of GSH showed in Fig. (8) .There were highly significant increase in exposed groups and this increases gradually with prolong exposure if compare with the control group. 


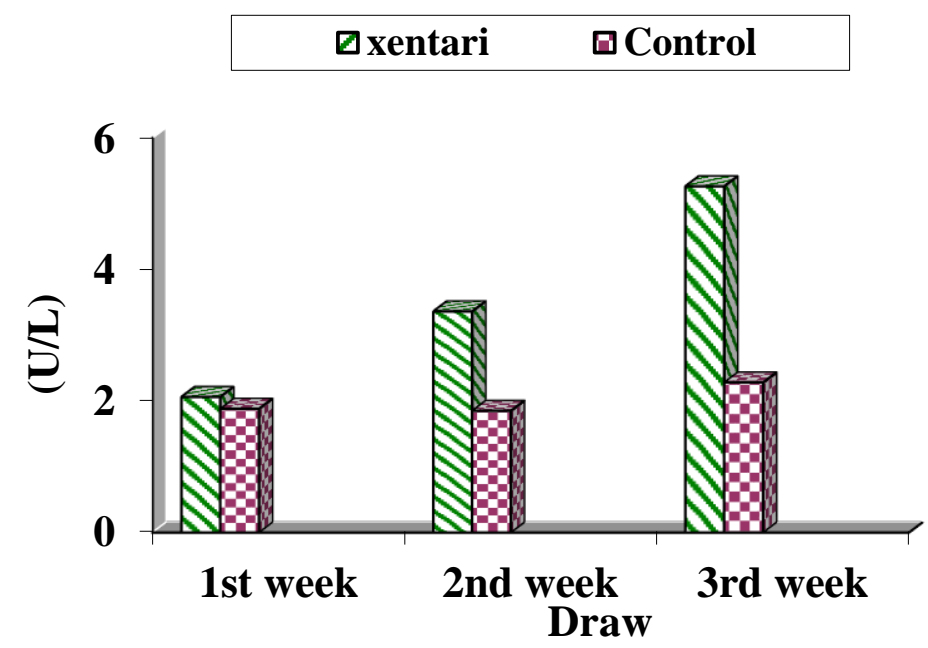

Fig. (6) Showed CAT level (U/L) in rat's serum at $1^{\text {st }}$, 2nd and $3^{\text {rd }}$ weeks of the experiment.

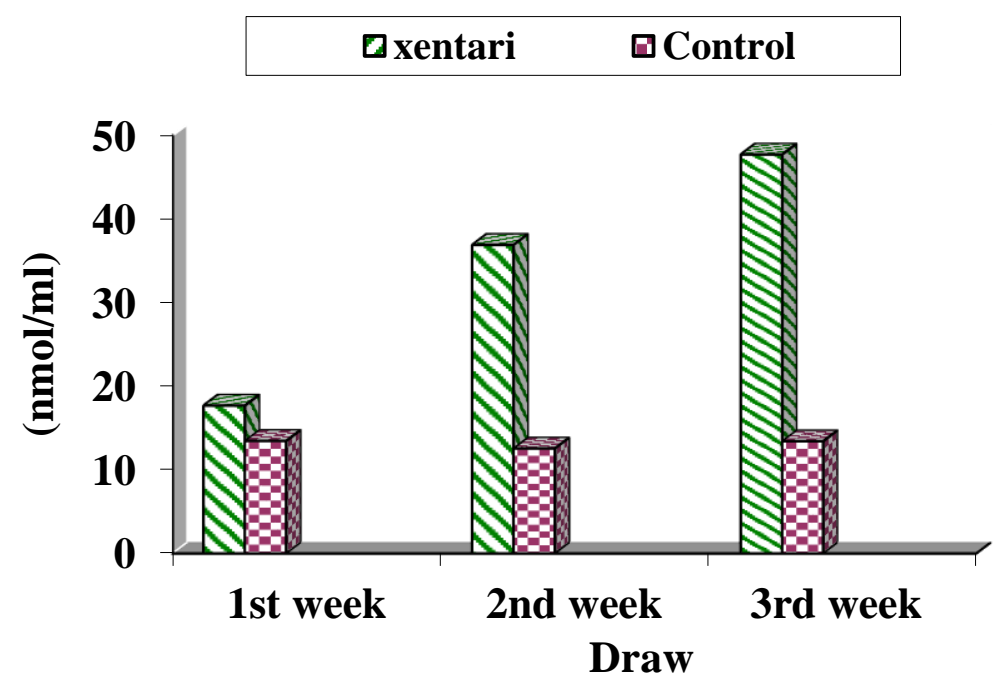

Fig. (7) Showed MDA level (nmol/ml) in rat's serum at $1^{\text {st }}$, 2nd and $3^{\text {rd }}$ weeks of the experiment. 


घxentari $\quad$ घControl

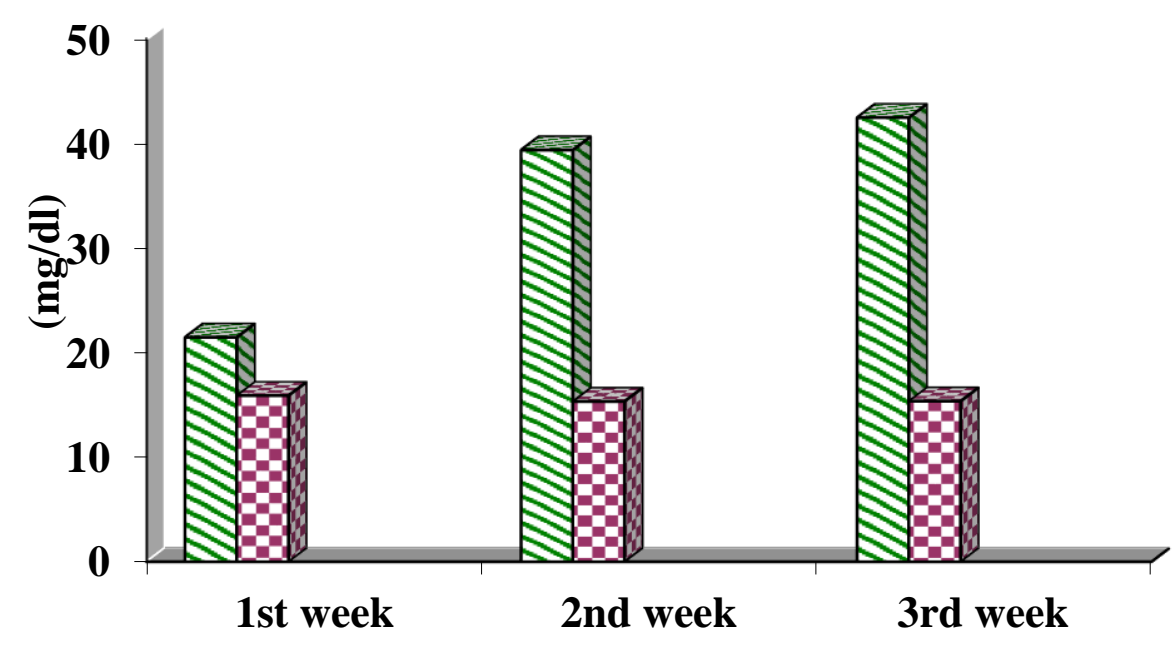

Fig. (8) Showed GSH level (mg/dl) in rat's serum at $1^{\text {st }}$, 2nd and $3^{\text {rd }}$ weeks of the experiment.

In the current study, we determine the saftey of Xen-Tari, it administrated to group of rat daily for 3 weeks. We determine change occur in serum biochemical which express liver and kidney function and measure change occure in activity of some antioxidant. Liver function as AST and ALT were determined to find out effect on hepatic system. Creatinine, Urea and Uric acid were estimated the effect on kidney function and excretory system. Antioxidant was performed as well to evaluate the degree of damage in body cell.

Liver is well known to have three main functions: storage, metabolism, and biosynthesis. Glucose was converted to glycogen and stored; when needed for energy, it is converted back to glucose. s. Numerous functional proteins such as, enzymes and bloodcoagulating factors are also synthesized by the liver. In addition, the liver, which contains numerous xenobiotic metabolizing enzymes, is the main site of xenobiotic metabolism (Hodgson and Levi 2004). The more specific parameter to liver was ALT, and thus is a better parameter for examining the liver injury. AST mainly found in mitochondria of hepatocytes. Thus, to evaluate liver injury, AST and ALT are the most common biochemical markers (Girish and Pradhar 2008).

Aminotransferases (ALT and AST) are cytoplasmic enzymes which increase in serum levels are attributed to damaged structural integrity of the liver resulting from their released into the blood circulation after the rupture of the plasma membranes ( Velmurugan et al. 2007). Our data revealed that Xen-Tari caused moderate liver damage indicated by increases in serum ALT, AST, levels along with compared with the control confirming the data obtained by (Rizzati et al. 2016).
Kidney has important role in removing wastes like creatinine,uric acid and urea, regulating the balance of electrolytes and controlling the body's fluid balance. For the kidneys to carry out their normal functions they have to be in good condition both functionally and structurally Creatinine is formed from creatine which stores energy in muscles in the form of phosphocreatine. When physical activity of the body is normal, the creatinine in blood remains within normal range. In agreement with this result (Luo et al. 2014). The present study revealed a significant increase in serum creatinine, uric acid and urea concentrations in xentari treated group in compared to control group. High urea level indicates kidney dysfunction, but its values varies with liver metabolic capacity, protein intake and renal perfusion so it gives a poor indication for measuring the renal function, however, creatinine shows the excretion of waste products through urine (Khan et al. 1996).

ROS are naturally generated in all mammalian cells during normal cellular respiration. Since ROS are cytotoxic molecules even when produced during normal respiration, for cell survival, they are naturally neutralized by the endogenous antioxidant defense system, primarily GSH, MDA, and CAT (Irazusta $\boldsymbol{e t}$ al. 2006). When there is an imbalance between ROS production and antioxidants, the cell becomes vulnerable to severe oxidative stress-induced damage. ROS can attack cell membranes and other cellular molecules, causing lipid peroxidation, protein oxidation, and DNA damage, which results in cell disruption and loss of function and can lead to diseases such as cancers, atherosclerosis, diabetes, and renal failure (Avery 2011). In the current study, MDA, CAT, GSH markers, were drastically increased this 
finding indicates cell membrane damage in cells, which is attributed to the increased production of $\mathrm{OH}$. The injury may be because of the liberated free radicals cause membrane lipid peroxidation and denaturation of both DNA and proteins. This damage leads to enzymatic inactivation and mitochondrial dysfunction that enhances ROS production via the disruption of the respiratory chain Catalase enzyme is a thiol-containing enzyme It is an important enzyme for the neutralization of ROS (Abdel Daim and ElGhoneimy 2015).

\section{References}

Abdel Daim MM and El-Ghoneimy A (2015) . Synergistic protective effects of ceftriaxone and ascorbic acid against subacute deltamerthrininduced nephrotoxicity in rats. Ren Fail;37:297304.

Aebi H. (1984). Catalase in vitro. Oxygen radicals in biological systems. Methods in enzymology. Vol. 105. Edited by L. Parker. Academic Press: Orlando, Fla;. p. 121-6.

Agarwal , R . K .; Singh , K . N .; Sirvastava , P . K. and Varma, B . K. (1979) Assessment of storage losses in wheat and diVerent refractions in periodic arrivals in mandis of Haryana. Bull Grain Technol 17:202-204.

Avery S.V. (2011). Molecular targets of oxidative stress. Biochem J 434, 201-210. Crossref, Medline, Google Scholar.

Bağcı, F. Yılmaz, A. Sait, E. (2014) Ankara ili hububat depolarında bulunan zararlı böcek türleri. Bitki Koruma Bülteni 54(1):69-78.

Bakr, E.M. (2005). A new software for measuring leaf area, and area damaged by tetranychus urticae Koch. J Appl Entomol, 129(3): 173-175.

Campbell , J.F. and Runnion , C. (2003) . Patch exploitation by female red Xour beetles, Tribolium castaneum. J Insect Sci 3(20) 8 pp Availableat http://www.insectscience.org/3.20.

Daglish , G .J .; Eelkema , M. and Harrison, L .M. (1996). Contorol of Sitophils oryzae (L.) (Coleoptera: Curculionidae) in paddy rice using chloropyrifos-methyl or fenintrothion in combination with severalother protectants. J Stored Prod Res 32:247-253.

Ellman, G.L. (1959). Tissue sulfhydryl groups. Arch. Biochem. Biophys., 82: 70-77.

Evans, D .E. (1987). Stored products In Burrn Aj, Coaker TH, Jepson PC (eds) Integrated pest management. Academic Press, London, pp 425461

Finney, D.J. (1971). Probit analysis: a statistical treatment of sigmoid response curve. Cambridge University Press, London. 333pp.

Girish, C., Pradhan, S.C. (2008). Drug development for liver diseases; focus on picroliv, ellagic acid and curcumin. Fundam. Clin. Pharmacol. 22 623632.
Hodgson, E. and Levi P. E. (2004). Interactions of piperonyl butoxide with cytochrome P450. In Piperonyl Butoxide: The Insecticide Synergist (Jones D. G. , Ed.), pp.41-53 Academic; San Diego, CA.

Hong K.J., Lee, W. Park, Y.J, Yang, J.O. (2018). First confirmation of the distribution of rice weevil, Sitophilus oryzae, in South Korea. Journal of Asia-Pacific Biodiversity 11:69-75.

Howe , R . W (1965). Losses caused by insects and mites in stored foods Nutr Abs Rev 35:285-302

Huang , J.; Pray, C. and Rozelle, S. (2002).Enhancing crops to feed the poor.

Husdan, H. and Rapaport, A. (1968): Estimation of creatinine by the Jaffe reaction. Clinic. Chemist. 14:222-226.

Irazusta, V. Cabiscol, E. Reverter-Branchat G., Ros, J., Tamarit, J. (2006). Manganese is the link between frataxin and iron-sulfur deficiency in the yeast model of Friedreich ataxia. J Biol Chem 281, 12227-12232. Crossref, Medline, Google Scholar

Khan, B.A., Abraham, A. Leelamma, S. (1996). Biochemical response in rats to the addition of curry leaf (Murraya koenigii) and mustard seeds (Brassica juncea) to the diet. Plant Foods Hum Nutr 49:295-299.

Laszczak-Dawid, A.; Kosewska, A.; Nietupski, M. and Ciepielewska, D. (2008). Rozwój spichrzela surynamskiego (Oryzaephilus surinamensis L.) na ziarnie pszenicy ozimej. [Development of saw toothed grain beetle (Oryzaephilus surinamensis) in winter wheat grain] Progress of Plant Protection /Postępy w Ochronie Roślin 48 (3): 908-912. (In Polish with English summary).

Luo X, Jiang L., Du B. , Wen Y. , Wang, M. X. , Beijing X. (2014). Acute Kidney Injury Trial (BAKIT) workgroup. A comparison of different diagnostic criteria of acute kidney injury in critically ill patients. Crit Care. Jul.

Mohamed, G. S. (2016). Pathogenicity of entomopathogenic fungus Beauveria bassiana and bacterium Bacillus thuringiensis var. kurstaki against the lesser grain borer Rhyzopertha dominica F. (Coleoptera: Bostrichidae) under laboratory conditions. Journal of Basic and Applied Mycology, 7:39-44.

Murray, R., Creatinine, K. A. Clin C. (1984) . The C. V. Mos by Co. Si louis. Tronto. Princeton;. p. 1261-6.

Noack, S. and Richmuth, C. H. (1978). Einrecherisches verfahren zur Bestimmung von beliebigen Dosis werten eines wirkstoffes aus empirisch Dosis- wirkungs- Daten mitt. Biol. Bundesanstalt fuer Land u. Forts-Wirtschaft, Berlin-Dahlem, Heft, 185: 1-49.

Ohkawa, H. Ohishi, N., Yagi, K. (1979). Assay for lipid peroxides in animal tissues by thiobarbituric acid reaction. Anal Biochem ;95:351-8. 
Rizzati V, Briand O, Guillou H, Gamet-Payrastre L (2016): Effects of pesticide mixtures in human and animal models: an update of the recent literature. Chem Biol Interact 254:231-246.

Safety Data Sheet (2002). Sodium metabisulphite. Issued 25.09.2002. pp 1-3 Revision No. 1.

Sinha, R. N. and Watters, F. L. (1985). Insect Pests of Flour Mills, Grain Elevators, and Feed Mills and Their Control. Agriculture Canada, Ottawa, 290 pp.

Tietz. N.W. (1995). Clinical Guide to Laboratory Tests, 3rd Edition. W.B. Saunders Co. Philadelphia, PA.
Trematerra, P. and Sciarretta, A. (2004). Spatial distribution of some beetles infesting a feed mill with spatio-temporal dynamics of Oryzaephilus surinamensis, Tribolium castaneum and Tribolium confusum. Journal of Stored Products Research 40 (4): 363-377.

Velmurugan, K., Chen, B., Miller, J. L., Azogue, S., Gurses, S., Hsu, T., (2007). Mycobacterium tuberculosis nuoG is a virulence gene that inhibits apoptosis of infected host cells. PLoS Pathog. 3:e110. doi: 10.1371/journal.ppat.003011.

\title{
تأثثير المركب الحيوى زنتارى على حشرتى خنفساء السورينام وسوسة الحبوب (القمح) وامانه على فئران التجرية

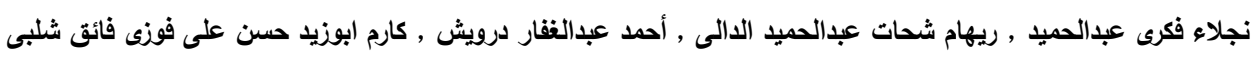

\begin{abstract}
أجريت هذه الدراسة فى معمل آفات الحبوب والمواد المخزونة بقسم وقاية النبات بكلية الزراعة - جامعة بنها , وذلك بغرض دراسة فاعلية مبيد الزنتارى الحيوى على حشرتين من حشرات المواد المخزونة هما , خنفساءالسورينام وسوسة الحبوب (القمح) عند ثلاث درجات حرارة (20 , 25

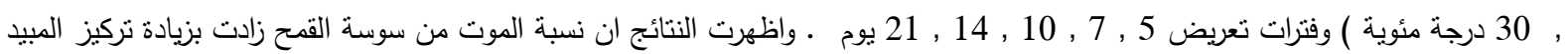
وكذلك فترة التعريض (5 , 7 , 10 , 14, 21 يوم) وزبادة درجات الحرارة ـ وكانت اعلى نسب موت مسجلة عند حرارة 30 درجة مئوية . بالنسبة

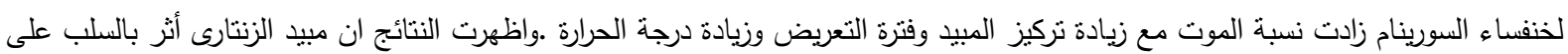
تكاثر الحشرات بعد المعاملة لكلا الحشرتين وان حشرة سوسة القمح كانت اكثر حساسية للمبيد من خنفساء السورينام حيث كانت نسب الموت لسوسة • القمح اعلى

وتم اجراء الجزء الخاص بتحديد امان مبيد الزنتاري فى مركز تربية حيوانات التجارب بكلية الطب البيطري واجراء الاختبارات على مصل الدم في معمل التميز العلمي بكلية الطب البيطري جامعة بنها و وذلك بغرض دراسة التاثير السمي ل ل مبيد الزنتارى الحيوى علي المؤثرات الكيميائية الحيوية ومضادات الاكسدة وقد أجريت هذه الدراسة علي 20 فأر من ذكور الفئران البالغة البيضاء ولمدة 3 أسبوع وقد تم تقسيمها إلي مجموعتين كل مجموعة عشر فأر كالتالي المجموعة الأولي: المجموعة الضابطة والمجموعة الثانية: المجموعة المستخدمة في التجربة بإعطائها مبيد الزنتاري المضاف الي الاكل يومبا ولمدة ثلاث اسابيع. وقد نم تجميع عينات الدم في نهاية الإسبوع الاول والثاني والثالث.

وقد أوضحث التحاليل الكيمبائية للسيروم حدوث زيادة معنوية في نشاط إنزيمات الالانين أمينوترانسنريز والإسباربيت أمبنوترانسفيربز والأكالين فوسفاتيز و وجود زيادة معنوية في مستوي اليوريا واليورك اسيد والكرياتينين وايضا ارتفاع مضادات الاكسده المتمثلك في كتاليز ومالوندهيد وجلوناثيون.
\end{abstract}

